\section{O. Mieczysław Paczkowski}

UMK, Toruń



3 (2010)

\title{
Egzegeza Rz 9 i kwestia wolnej woli w ujęciu Orygenesa
}

Jednym z głównych filarów systemu antropologiczno-teologicznego Orygenesa było przekonanie, że człowiek jest istotą zdolną do wolnego wyboru i moralnego działania ${ }^{1}$. W całym swym dziele autor ten pozostał „,nieugiętym rzecznikiem wolnej woli człowieka"2. To niewątpliwie trafne określenie, chociaż wolna wola dla starożytnego pisarza oznaczała coś innego niż dla współczesnego człowieka.

\section{Kwestia wolnej woli w systemie teologicznym Orygenesa}

Problemy wolnej woli, wolności wyboru i samookreślenia stanowią podstawę antropologii chrześcijańskiej. Od wolności wyboru uzależniony jest status osoby ludzkiej w kontekście stworzenia, godności człowieka i jego możliwości. Bóg jest odkupicielem upadku człowieka, a w Jego zamyśle harmonizują zarówno wolne aktu człowieka, jak i działania Opatrzności Boskiej i nieuniknione następstwa praw natury. Przeciwko tym zasadom występowali zwolennicy determinizmu i ślepego fatum. W starożytnym chrześcijaństwie miejsce fatalistów zajęli gnostycy ${ }^{3}$, których zwalczano ukazując kwestię pochwały i nagany, zakładających przekonanie o istnieniu wolnej woli ${ }^{4}$ Dla Ireneusza z Lyonu to właś-

1 Był to również argument Tertuliana polemizującego ze zwolennikami Marcjona; por. Adversus Marcionem II,6,1-8; 7,1-5.

2 Por. H. Crouzel [tłum. pl. J. Margański], Orygenes, Bydgoszcz 1996, s. 259.

3 Por. Cyceron, De fato XVII,40. Por. przede wszystkim D. Amanci, Fatalisme et liberté dans l'antiquité grecque. Recherches sur la survivance de l'argumentation morale antifataliste de Carnéade chez les philosophes grecs et les théologiem chretiens des quatre premiers siècles, Lowanium 1945 (druk anastatyczny Amsterdam 1973), s. 304 przypis 2. Ponadto por. M.E. Reesor, Fate and Possibility in Early Stoic Philosophy, Phoe 19 (1965), s. 285-297. Na temat ogólnego pojęcia przeznaczenia i opatrzności por. A. Magris, L'idea del destino nel pensiero antico, tom 1-2, Triest 1985.

4 Na temat pojęcia wolnej woli w starożytności klasycznej por. A. Dihle, The Theory of Will in Classical Antiquity, Berkeley-Los Angeles-Londyn 1982, s. 111-112. Natomiast jeśli 
nie wolna wola była elementem reprezentatywnym obrazu Boga w człowieku' Klemens Aleksandryjski uważa wolność stanowienia o sobie za przywilej człowieka, udzielony mu przez Zbawcę ${ }^{6}$. Tematyka wolności wyboru została zaczerpnięta z etyki Arystotelesa. Poruszone w Etyce Nikomachejskiej zagadnienie wstępnego wyboru wielki grecki filozof rozproszył na wielu stronicach swoich pism jako problem intencji moralnej i samego zbawienia ${ }^{7}$.

Orygenes polemizuje $\mathrm{z}$ determinizmem pogańskim i gnostycką ideą znoszącą wolną wolę istot rozumnych ${ }^{8}$. Także i w tej materii aleksandryjski myśliciel starał się nadać spójność swemu szerokiemu systemowi filozoficzno-teologicznemu, a nie być wyłącznie echem swych poprzedników ${ }^{9}$. Kwestie wolnej woli (autexoúsion) i wolności (eleuthería) ${ }^{10}$ zazębiają się, co jednak nie oznacza przemieszania pojęć. Pojęcie liberum arbitrium, według łacińskich tłumaczy Orygenesa, określało również samo decydowanie, gdy należy dokonywać wyboru i wolność zawęża się do tej koncepcji. Warto pamiętać, że obrona wolnej woli, przeciw gnostykom $\mathrm{z}$ jednej strony, a filozofiom deterministycznym $\mathrm{z}$ drugiej, była uważana przez mistrza z Aleksandrii za pilne i konieczne zadanie ${ }^{11}$.

chodzi o zhellenizowany judaizm por. D.S. Winston, Freedom and Determinism in Greek Philosophy and Jewish Hellenistic Wisdom, Studia Philonica 2 (1973), s. 40-50; tenże, Freedom and Determinism in Philo of Alexandria, tamże 3 (1974-75), s. 47-70.

5 Por. Adversus haereses IV,4,3; 37,4; 38,4.

6 „My zaś za pośrednictwem Pisma Świętego dowiedzieliśmy się, że pełną, niczym nie skrępowaną wolność pozytywnego wyboru lub odrzucenia otrzymali ludzie od samego Pana”. Stromata II,12,1. Por. C. Mondésert (wstęp) - M. Caster (tłum. i przypisy), Clément d'Alexandrie. Les Stromates I (SC 30), Paryż 1951.

7 Temat wolnej woli stanowi treść III księgi dzieła Arystotelesa. Por. D. Gromska (tłum.), Arystoteles. Etyka Nikomachejska, Warszawa 1956. Odnośnie do tej kwestii por. C. Natali, Responsability and Determinism in Aristotelian ethics, w: M. Canto-Sperber P. Pellegrin (wyd.), Le Style de la pensée: Recueil de texts en hommage à Jacques Brunschwig, Paryż 2002, s. 267-295.

8 Por. Philocalia 21,1; 16. Por. E. Norelli, Marcione e gli gnostici sul libero arbitrio e la polemica di Origene, w: L. Perrone (red.), Il cuore indurito del Faraone Origene e il problema del libero arbitrio (Origini 3: Studi e Testi del CISEC), Bolonia 1992, s. 1-30.

9 „Wielu wyznawców wiary Chrystusowej różni się między sobą nie tylko w poglądach na temat spraw drobnych, lecz również w zakresie problemów ważnych i zasadniczych..., dlatego też uważam za konieczne najpierw przedstawić pewną zasadę i określoną regułę dotyczącą tej kwestii, a dopiero potem zastanowić się nad pozostałymi problemami”. De principiis, praef. 2. Por. H. Crouzel - M. Simonetti, Origène. Traité des principes, tom 1-5 (SC 252; 253; 268; 269; 312), Paryż 1978; 1980; 1984; S. Kalinkowski (tłum.) - W. Stanula - W. Myszor (oprac.), Orygenes. O zasadach (Pisma Starochrześcijańskich Pisarzy 23), Warszawa 1979.

10 Odnośnie do tych pojęć por. L.R. Holliday, Will Satan Be Saved? Reconsidering Origen's Theory of Volition in Peri Archon, Vigiliae Christianae 63 (2009), s. 9-14.

11 O roli tego problemu w myśli Orygenesa por. Philocalia, XXI,16. 
Kontekst polemiczny nie stwarzał większych problemów w komentarzu egzegetycznym, bowiem nie należy zapominać, że właśnie dyskusje odnośnie błędów doktrynalnych zasugerowały Orygenesowi systematyczny komentarz do Rz ${ }^{12}$. Należałoby w tym miejscu przywołać Marcjona ${ }^{13} \mathrm{i}$ jego koncepcję wolności wyboru i zbawienia oraz przypomnieć fatalizm i determinizm walentynian ${ }^{14}$. Z kolei wolność rozświetla blask Objawienia, a prawdziwie wolnym jest jedynie człowiek uwolniony od grzechu, a więc taki, który przyjął Bożą prawdę ${ }^{15}$. W sposób nierozdzielny wolna wola łączy się także $\mathrm{z}$ zagadnieniem wybrania i predestynacji, a swoje dopełnienie znajduje $\mathrm{w}$ nauce o wszechwiedzy Boga. Czuwanie Stwórcy nad człowiekiem to pronoia ${ }^{16}$ utożsamiana $\mathrm{z}$ opatrznością ${ }^{17}$.

W swoich poszukiwaniach Orygenes nie ogranicza się jedynie do wspomnianych wcześniej zagadnień filozoficzno teologicznych. Nie brak odnośników do perykop biblijnych, bardzo często powracających jako narzucone przez nieortodoksyjną egzegezę. Potwierdza to cała księga III De principiis ${ }^{18}$, którą Orygenes poświęcił problematyce wolnej woli, zazębiając kwestie biblijne i refleksję filozoficzno-teologiczną ${ }^{19}$. Jest to w pewnym stopniu ujęcie „katechi-

12 Por. Commentarius in Rom [praefatio]; P. Gorday, Principles of patristic exegesis. Romans 9-11 in Origen, John Chrysostom and Augustine (Studies in the Bible and early Christianity 4), Nowy Jork-Toronto 1983.

13 Marcjon był pierwszym, który ustanowił taxis - ordo w Corpus Paulinum Pierwsze miejsce zajmował Ga, który według świadectwa Tertuliana stanowił „główny list przeciwko judaizmowi"; Adversus Marcionem V,2,19. Por. A. Kroymann, E.Dekkers, J.G.Ph. Borleffs, J.H. Waszink (wyd.), Quinti Septimi Florentis Tertulliani opera, pars I, tom 1 (CCL [= Corpus Christianorum, Series Latina] 1), Turnhout 1954; W. Myszor (wstęp i przyp.) - S. Ryznar (tłum.), Tertulian. Przeciw Marcjonowi (Pisma Starochrześcijańskich Pisarzy 58), Warszawa 1994.

14 Por. E.H. Pagels, The Valentinian Claim to Esoteric Exegesis of Romans as Basis for Anthropological Theory, Vigiliae Christianae 26 (1972), s. 256-259. Osobny problem stanowiło właściwe zrozumienie myśli Apostoła, który wyrażał się w sposób dosyć trudny.

15 Por. L. Perrone, Libero arbitrio, w: A. Monaci Castagno (red.), Origene. Dizionario. La cultura, il pensiero, le opere, Rzym 2000, s. 239.

16 Por. De oratione 5,2-3; wyd. krytyczne w: P. Koetschau (wyd.), Origenes Werke, tom 1; GCS 3 [= Die Griechlischen Christlichen Schriftseller]), Leipzig 1899.

17 Odnośnie do kwestii opatrzności u Orygenesa por. L. Perrone, Provvidenza, w: A. Monaci Castagno (red.), Origene. Dizionario, s. 392-396.

18 Por. E. Daley, Origen's “De principiis": A Guide to the "Principles" of Christian Scriptural Interpretation, w: J.F. Petruccione (red.), Nova et Vetera: Patristic Studies in Honor of Thomas Patrick Halton, Washington 1998.

19 B.D. Jackson, Sources of Origen's Doctrine of Freedom, Church History 35 (1966), s. 16-21. Na biegunowość i konfliktowość tych zasad zwraca uwagę H. Holz, Über den Begriff des Willens und der Freiheit bei Origenes, Neue Zeitschrift für systematischeTheologie und Religionsphilosophie 12 (1970), s. 63-84. Kwestię rozwija L. Perrone, La parrhêsia di Mosé: 
zmowe", gdzie jednak zawsze na pierwszy plan wysuwały się sugestie tekstu Pawłowego. Fakt, że Bóg respektuje wybór człowieka i nigdy go nie zniewala, to niezmienna myśl w doktrynie Adamancjusza ${ }^{20}$. Aleksandryjski myśliciel odrzucał twierdzenie, że Boskie dzieło byłoby doskonalsze, gdyby Bóg pozbawił swoje stworzenie tej tak ważnej cechy, jaką jest zdolność wolnego wyboru dobra ze względu na nie samo.

Rozważania Orygenesa dotyczące wolnej woli bazują na analizie aktu wolnego bytu i są ukierunkowane na udowodnienie, że działanie wypływa z rozumowania, ponieważ człowiek nie jest zdeterminowany przez „obrazy rzeczy” i może dać lub nie swoje przyzwolenie. Osąd nie jest niczym ograniczony ${ }^{21}$, a wolna wola jest ściśle związana $\mathrm{z}$ godnością bytu duchowego lub stworzenia cielesnego obdarzonego dusząa ${ }^{22}$. Wolność warunkuje wartość aktu ludzkiego i czyni go zasługującym lub skazującymi na potępienie ${ }^{23}$. To jedna $z$ podstawowych cech wyróżniających stworzenia rozumne. Wolność, którą obdarzony jest rozumny człowiek implikuje jednak pewien rodzaj niestałości. „Stworzenia... zostały obdarzone wolną wolą, i właśnie wolna wola pociągnęła każdą poszczególną istotę albo do rozwoju poprzez naśladowanie Boga, albo popchnęła ku upadkowi wskutek niedbałości"24. Orygenes wyjaśnia to nieco dokładniej w jednym z wcześniejszych fragmentów dzieła $O$ zasadach:

Natury rozumne $[\ldots]$ są zmienne i niestałe [...]. Istnienie nie jest wieczną własnością, lecz darem Bożym [...] wszelki dar może zostać odebrany i może przepaść [...]. [Przyczyną utraty dobra] jest fakt, że poruszenia duchów nie są kierowane należycie i rozsądnie. Stwórca zezwolił stworzonym przez siebie Bytom dobrowolne i swobod-

l'argomentazione di Origene nel Trattato sul libero arbitrio e il metodo della "quaestiones et responsiones", tenże (red.), Il cuore indurito del Faraone, s. 31-64.

20 W wykładzie „reguły wiary” w De principiis I,5 Orygenens mówi o wolnej woli, w którą wyposażona jest dusza rozumna. Autor omawia całościowo artykuły wiary przyjmowane przez zwykłych chrześcijan (por. Commentarius in Joh. XIII,16,98) i wyjaśnia ich treść (por. Commentarius in I Cor. [fragm.]). W jego koncepcji tradycja była równoznaczna z kerygmatem przekazanym przez apostołów (por. De principiis III,1,1). Por. J.N.D. Kelly, Początki doktryny chrześcijańskiej, Warszawa 1988, s. 43.

21 Por. De principiis III, $5,4$.

22 Por. Commentarius in Rom... VIII,11. Cytujemy tłum. tego dzieła wg S. Kalinkowski (tłum. i oprac.) - W. Stanula (wstęp), Orygenes. Komentarz do Listu św. Pawła do Rzymian (Pisma Starochrześcijańskich Pisarzy 57), Warszawa 1993.

23 Por. De principiis III,1,2-5. Fragment De principiis III,1,2-5 ma wiele analogii do De oratione 6,1-2. Por. Ph.J. Van Der Eijk, Origenes' Verteidigung des Freien Willens in De oratione 6,1-2, Vigiliae Christianae 42 (1988), s. 339-351.

24 De principiis II,9,6. Na temat upadku istot rozumnych por. J.W. Trigg, Origen: The Bible and Philosophy in the Third-century Church, Atlanta 1983, s. 109. 
ne działanie, aby powstało w nich ich własne dobro [...]. Jednakże lenistwo i wstręt do wysiłku e zachowaniu dobra oraz niechęć i lekceważenie wyższych wartości dały początek odchodzeniu od tego co dobre ${ }^{25}$.

Widać tutaj w całej pełni teorię działania $\mathrm{z}$ wyboru, wykluczającego działanie ślepego przeznaczenia $\left(\right.$ fatum $\left.^{26}\right)$. W istnieniu bytu rozumnego następuje duchowy rozwój lub degradacja. Wszystko zależy od ludzkiej umiejętności rozróżniania między dobrem prawdziwym a pozornym, między prawdą a fałszem, bytem a niebytem.

Według kosmologii Orygenesa wszystkie stworzenia podlegają zmianom i ruchowi ${ }^{27}$. W sposób dosyć zawiły Adamancjusz wyjaśnia różnorodność bytów rozumnych, cielesnych i bezcielesnych ${ }^{28}$. $\mathrm{Z}$ ich hierarchii wywodzi istnienie wolnej woli, a różnorodność natur opiera na różnicy opcji. „Stwórca wszechrzeczy zastosował pewne zarodki i przyczyny różnorodności, aby stworzyć różnorodny i zmienny świat, stosownie do różnorodnych umysłów"29 Kieruje ostrze swej polemiki przeciwko tym, którzy potępiają cielesność i widzą w niej przyczynę zła. Dla Aleksandryjczyka to niewłaściwe użycie wolnej woli przyczyniła się do powstania $z \mathrm{a}^{30}$. To właśnie jego rozplenienie się blokuje proces reedukacji i nawrócenia $^{31}$. Adamancjusz zwraca uwagę, że „zewnętrzne okoliczności nie zależą od naszej woli; od nas jednakże zależy, jak wykorzystamy te okoliczności - dobrze czy źle, bo tkwiący w nas rozum osądza i rozstrzyga, w jaki sposób należy z nich korzystac'" ${ }^{2}$. To racjonalny osąd pozwala podejmować decyzje i uniezależniać się od wpływów otoczenia ${ }^{33}$. Orygenes wyjaśnia bowiem, że „przy określonych możliwych posunięciach przed trybunałem naszego serca i jak gdyby w obecności sędziego rozpatruje się rzecz z przeciwstawnych punktów widzenia, ażeby dopiero po wyłożeniu motywów rozum wydał wyrok w sprawie działania"34.

25 De principiis II,9,2.

26 Por. J. Gould, The Stoic Concept of Fate, Journal of the History of Ideas 35 (1978), s. 22.

27 Jest to tematyka typowo stoicka. Por. np. H. von Arnim, Stoicorum veterum fragmenta, tom 2, Stuttgart 1964, s. 174,30-39. Pojawia się ona również u Filona Aleksandryjskiego. Por. Leges allegoriae II,22; De rerum divinarum heres sit 137.

28 Por. De principiis I,8,1; Hom. in Genesim XV,5; Contra Celsum V,29.

29 De principiis II,9,2.

30 Por. Contra Celsum IV,65.

31 Por. De principiis I,6,3.

32 De principiis III, 1,5 .

33 Por. M.C. Paczkowski, Proces kształtowania woli i wyrabiania nawyków według Orygenesa, Paedagogia Christiana 1/19 (2007), s. 19-22. Wiele z powyższych wątków zostało zaczerpniętych z tego opracowania.

34 De principiis III,1,4. 
Aleksandryjczyk uznaje więc wolność sytuacyjną ${ }^{35}$, zbieżną w pewnym stopniu z Sartrowskim „paradoksem wolności ${ }^{36}$.

Wpływ Boga to dla Orygenesa klucz do zrozumienia mechanizmu wolnej woli ${ }^{37}$. Bóg obdarza rozumne istoty swoimi darami, które stanowią Jego nierozłączne przymioty i strzeże, aby ich wola nie zwyrodniała przez upadek ${ }^{38}$. Adamancjusz dostrzega te zasady $\mathrm{u}$ apostoła Pawła, bowiem to on „przemawia do nas jako do istot dysponujących wolną wolę - mówi do nas jak do tych, którzy noszą w sobie przyczyny zbawienia i potępienia" ${ }^{39}$. Aleksandryjczyk nie dostrzega możliwości, aby Bóg, który stworzył wszystkie byty rozumne jako równe co do godności i podstawowych cech, pozostawił je samym sobie, gdy odstąpią od swej pierwotnej doskonałości. Ponadto stosuje wobec nich ozdrowieńcze kary $^{40}$. Według optyki chrześcijańskiej zbawienie człowieka zależy od osobistego wyboru, który stanowi nieodzowny warunek wszelkiego postępu w cnocie. Przy

35 „To, co działa na nas z zewnątrz, jest niezależne od naszej woli - nie możemy sprawić, żeby nie oddziaływało; jednak ocena i decyzja, jak mamy zużytkować to, co na nas oddziaływa, jest już tylko przedmiotem pracy owego tkwiącego w nas rozumu, to znaczy naszego sądu; gdy oddziałują na nas zewnętrzne impulsy, opieramy się na osądzie tego rozumu w tym, co sam rozum zaaprobuje, bo jego decyzja kieruje naszymi naturalnymi poczynaniami w kierunku dobra lub zła”. De principiis III,1,3.

36 „Wolność istnieje tylko w [określonej] sytuacji, a sytuacja powstaje tylko dzięki wolności”; J.-P. Sartre, Being and Nothingness, w: R.C. Solomon (red.), Phenomenology and Existentialism, Nowy Jork 1972, s. 465.

37 Powyższe kwestie zostają rozwinięte w: De principiis III,1,8-9; Commentarius in Rom. VIII,11-13; IX,2; Philocalia 21-27. Komentarz do Rz w tłum. wł. w: F. Cocchini, Origene. Commento alla lettera ai Romani, tom 1 („Ascolta Israele!”. Commenti alle Scritture delle tradizioni ebraica e cristiana 2), Casale Monferrato 1985. Dyskusję nad problemem wolności u Orygenesa podejmują: M. Simonetti, I Principi di Origene, Turyn 1968, s. 364, przypis 1; E. Junod, Origène. Philocalie 21-27: Sur le libre arbitre, s. 19-20; R. Calonne, Le libre arbitre selon le Traité des principes d'Origène, Boulletin de Littérature Ecclésiastique 89 (1988), s. 243-262; B.D. Jackson, Sources oj Origen's doctrine oj freedom, Church History 35 (1966), s. 13-23; H. Holz, Über den Begriff des Willens und der Freiheit bei Origenes, Neue Zeitschrift für Theologie und Religionsphilosophie 12 (1970), s. 63-84. Szerszy kontekst przedstawiają D. Amand, Fatalisme et liberté dans l'antiquité grecque. Recherches sur la survivance de l'argumentation morale antifataliste de Carnéade chez les philosophes grecs et lei théologiens chrétiem des quatre premiers siècles, Lowanium 1945 (druk anastatyczny, Amsterdam 1973) i U. Berner, Untersuchungen zur Verwendung des Synkretismus-Begriffes, s. 153.

38 Orygenes odwołuje się do określenia katabolê, oznaczającego w Nowym Testamencie „Założenie świata" (por. Mt 13;35; Łk 11,50; J 17,24; Ef 1,4; Hbr 4,3; 1 P 1,20; Ap 13,8), lecz w przypadku stworzenia rzeczywistości materialnej chodzi o „ciążenie ku dołowi”. Por. De principiis II, 8,4; III,5,4-5.

39 De principiis III,1,6. Wypowiedź Orygenesa kończy dłuższy cytat z Rz 2,4-10.

40 Por. Contra Celsum VI,56. 
tej okazji autor De principiis nawiązuje do standardowej koncepcji platońskiej, według której brak racjonalności (logos) oznacza zniewolenie ${ }^{41}$. Odrzucając rozumne działanie przestaje się być wolnym i popada się w niewolę ignorancji ${ }^{42}$, nawet nie zdając sobie z tego sprawy. Nie ulega wątpliwości, że

Stworzenie rozumne [...] potrafi oceniać i rozróżniać naturalne działania, może jedne z nich potępiać i odrzucać, a inne akceptować i przyjmować, i dzięki ocenie rozumu poczynania ludzkie mogą się zwracać ku chwalebnemu życiu. Wynika stąd wniosek, że istota rozumu tkwiącego w człowieku ma w sobie zdolność rozróżniania dobra i zła, a gdy dokona tego rozróżnienia, posiada możliwość wyboru tego, co uznała za słuszne: wybierając to, co dobre, zasługuje na pochwałę, idąc zaś za tym, co szpetne i złe, słusznie zostanie uznana za godną potępienia ${ }^{43}$.

Prawdziwa wolność polega na właściwym postępowaniu i ciągłym wzroście duchowym. Orygenes niejednokrotnie przypomina zasadę, według której apostoł nawołuje do naśladowania go, gdyż poszedł on w ślady Chrystusa (por. 1 Kor $4,16)^{44}$. Do tych zasad Orygenes dodaje inne, tym razem na wskroś biblijne rozwiązanie problemu. Polega ono na umiejscowieniu w czasie różnych przypadków wybrania albo też nieprzyjaźni ze strony Boga. Trzeba jednak zwrócić uwagę, że ramy te nie zamykają się jedynie w obrębie tego świata, lecz są rozciągnięte do czasów przyszłych i wcześniejszych (eschatologia i preegzystencja) ${ }^{45}$.

Działanie wolnej woli nie może w żaden sposób doprowadzić do ostatecznego zniszczenia i potępienia. Dlatego Orygenes mówi nawet o dopełnieniu się liczby wybranych ${ }^{46}$, postępujących według „wieczystej Ewangelii”, do której nic nie zostanie dodane ${ }^{47}$. Jest to jeden $\mathrm{z}$ aspektów apokatastazy ${ }^{48}$, bowiem na końcu czasów nastąpi odnowienie wszystkiego w Bogu i wszystko powróci do swego duchowego i chwalebnego stanu. Ukoronowaniem istnienia wszechświata jest powszechna odnowa.

41 Por. De principiis III,5,4. Por. Platon, Republica 533 c-d; Plotyn, Enneady I,3,5-6.

42 Por. De principiis I,4,1. Alternatywna interpretacja w: L. Hennessey, The Place of Saints and Sinners After Death, w: C. Kannengiesser, W.L. Petersen (red.), Origen of Alexandria: His World and His Legacy, Indianapolis 1988, s. 310, przypis 46.

43 De principiis III,1,3.

44 Por. Homiliae in Ez. IV,5; VII,3; Commentarius in Matth. X,15; De principiis IV,4,4.

45 Por. A. Monaci Castagno, Elezione, giustizia e libero arbitrio in Origene, s. 241.

46 Por. A. Monaci, Apocalisse ed escatologia nellopera di Origene, Augustinianum 18 (1978), s. 148.

47 Por. De principiis III,6; IV,3.

48 E. Moore, Origen of Alexandria and apokatastasis: Some Notes on the Development of a Noble Notion, Quodlibet Journal: 5/1 (2003), wersja elektroniczna wg: www.quodlibet.net. 
[Bóg] przywołuje stworzenia do jednolitej harmonii w uczynkach i chęciach... Wszystkie poszczególne duchy lub dusze - czy jak tam nazwiemy istoty rozumne nie są zmuszane do działania wbrew wolnej woli i wbrew chęciom swojego umysłu; w przeciwnym wypadku można by sądzić, że zabrano im wolną wolę, a to przecież zmieniłoby jakość ich natury; różnorodne ich poczynania w sposób stosowny i korzystny zostały uzgodnione $\mathrm{z}$ harmonią jednolitego świata ${ }^{49}$.

Ma się tu do czynienia ze stoickim podkreśleniem jedności i spójności świa$\mathrm{ta}^{50}$, co służy naszemu autorowi do przywołania jedności woli w zharmonizowanej całości stworzenia.

\section{Wolność wyboru w kontekście Rz 9}

Myliłby się jednak ten, kto uważa refleksję Orygenesa nad wolnością wyboru za zredukowaną wyłącznie do sfery filozoficzno-teologicznej. W kwestii wolnej woli element biblijny odgrywa niepoślednią rolę, bowiem trudności w pojmowaniu tej kwestii, nie pojawiły tylko na skutek zarzutów heretyków. Wydaje się, że dużo większym problemem dla Aleksandryjczyka były wnioski płynące z uważnej lektury Pisma Świętego, a szczególnie kilku znaczących fragmentów. Trudno zatrzymywać się i komentować znaną deklarację metodologiczną Orygenesa w De principiis ${ }^{51}$. Ponadto dotyczy ona Starego Testamentu, a egzegeza Corpus Paulinum rządzi się swoimi prawami. Teksty apostoła narodów miały charakter dydaktyczny i parenetyczny, stąd było możliwe poddawanie ich interpretacji duchowej bez konieczności zastosowania alegorii. Kanon Muratoriego ${ }^{52}$ z końca II wieku jest pośrednim świadkiem popularności całego Corpus Paulinum ${ }^{53}$.

\footnotetext{
49 De principiis II,1,2.

50 Por. Stoicorum veterum fragmenta..., tom 2, s. 441, 447, 548-552. Por. także Contra Celsum IV,54.

51 „Z samego Pisma czerpiemy naukę, jak o nim należy myśleć. U Salomona w Księdze Przysłów znajdujemy taki nakaz odnoszący się do przestrzegania Pisma Świętego: «I ty, powiada, zapisz sobie potrójnie w pamięci i rozumie, abyś mógł prawdziwie odpowiadać tym, którzy cię pytać będą» (por. Prz 22,20.21). Potrójnie więc należy zapisywać w swej duszy wszelkie rozumienie pism Bożych: to znaczy żeby każdy prosty człowiek czerpał zbudowanie z samego, że tak powiem, ciała Pisma - bo tak nazywamy pojmowanie zwyczajne i historyczne; jeśli zaś ktoś zaczął już czynić postępy i może patrzeć nieco szerzej, niech się buduje samą duszą Pisma; ci zaś, którzy są doskonali i podobni do tych, o których mówi Apostoł: «Głosimy mądrość między doskonałymi, ale nie mądrość tego świata ani mądrość władców tego świata, którzy giną, lecz głosimy mądrość Bożą ukrytą w tajemnicy, którą przed wiekami Bóg przeznaczył dla naszej chwały» (1 Kor 2, 6-7)"; tamże IV,2.

52 Por. G. Bardy, Muratori (canon de), w: L. Pirot, A. Robert, H. Cazelles (red.), Dictionnaire de la Bible - Supplément, tom 5, Paryż 1955, kol. 1402.

53 Kanon wzmiankuje listy apostoła dwukrotnie. Najpierw podaje ich krótką charakterystykę, posługując się kryterium chronologicznym, a następnie wskazuje, że Apostoł pisał do
} 
W dużej mierze egzegeza Orygenesa uwarunkowana jest wymogami polemiki przeciwko gnostykom, którzy z tekstu Pawłowego wydobywali niektóre ważne argumenty biblijne do swego determinizmu antropologicznego $0^{54}$. Niektóre teksty biblijne powodowały problemy w ujmowaniu tradycyjnej nauki o wolnej woli, uznanej przecież powszechnie w nauczaniu Kościoła. W Komentarzu do Rz tekst biblijny przywoływał więc problematykę tego rodzaju ${ }^{55}$. Dodać należy, że dzieło egzegetyczne poświęcone $\mathrm{Rz}^{56}$ jest wcześniejsze niż Komentarz do $M t$ i datowane przed 224 rokiem $^{57}$. Mimo dogłębnej analizy pisma apostoła narodów Orygenes nie pozostawił kompletnego wykazu pism Pawłowych, jednak interesował się ich chronologią na podstawie jego postępu duchowego ${ }^{58}$.

Warto też zwrócić uwagę na metodologię tłumacza Orygenesa - Rufina z Akwilei, który posługuje się starą wersją łacińską tłumaczenia Rz. Wyraźny przykład stanowi Rz 9,11-12, który w tłumaczeniu De principiis odwzorowuje tekst grecki. W tłumaczeniu tego właśnie dzieła Orygenes jest mocno zlatynizowany ${ }^{59}$.

W swojej egzegezie Adamancjusz niestrudzenie powraca do tematu wolności wyboru, wzbogacając swą refleksję o nowe wymiary i charakterystyczne szczegóły. Pod tym względem znacząco przedstawia się egzegeza niektórych fragmentów biblijnych. Chodziło głównie o perykopy mówiące o wybraństwie i odrzuceniu na przykładzie dziejów narodu wybranego. Stosunek Boga do Izraela w sposób nieunikniony wpływał na wizję relacji pomiędzy wolą Stwórcy a wolnością człowieka.

Ważnym powodem takiego nastawienia Orygenesa był fakt, że apostoł Paweł odwoływał się do Starego Testamentu w kontekście, w którym splot Bożego wy-

siedmiu Kościołów, „idąc śladem swego poprzednika Jana”; por. N.A. Dahl, Welche Ordnung der Paulusbriefe wird vom Muratorischen Kanon voraugesetzt?, Zeitschrift für die neutestamentliche Wissenschaft und die Kunde der älteren Kirche 52 (1961), s. 39-53. Wg Kanonu Rz został zredagowany, aby „ukazać, że Chrystus jest sensem Pisma Świętego”.

54 Por. M. Simonetti, Między dosłownością a alegoria Przyczynek do historii egzegezy patrystycznej (Myśl teologiczna 26), Kraków 2000, s. 86; 94.

55 Oprócz perykop, które explicite nawiązywały do tej problematyki, Orygenes dyskutuje problem wolnej decyzji także przy okazji egzegezy Rz 11,28-36 (por. Commentarius in Rom. VIII,13) i Rz 12,4-5 (por. Commentarius in Rom. IX,2).

56 Problematykę tego dzieła przedstawia F. Cocchini, Problematiche relative a $\mathrm{Rm} 9 \mathrm{nel}$ Commento di Origene alla Lettera ai Romani, Annali di storia dell'segesi 3 (1986), s. 85-97.

57 Por. J. Quasten, Patrologia, tom 1, Casale Monferrato 1983, s. 326.

58 Por. Contra Celsum III,30. Orygenes wylicza listy w następującym porządku: Ef, Kol, 1-2 Tes, Fil, Rz. Por. również Commentarius in Rom. [praef.]. Główne opracowanie tematu to F. Cocchini, Il Paolo di Origene: esemplarità di una risposta antropologica, w: L. Padovese (wyd.), Atti del I Simposio su S. Paolo a Tarso (Turchia: la Chiesa e la sua storia 2), Rzym 1993, s. 123-127.

59 Orignenes Romanus; por. Praef. Rufuni 3,4. 
boru i Bożej nieprzyjaźni, chwały i potępienia człowieka, sprawiedliwości Boga, a wolności człowieka, jawi się w całej swej dramatyczności. Podobnie jak w każdej innej kwestii, także i tu Aleksandryjczyk prezentuje wielką różnorodność interpretacji i powodów uzasadniających przyjęcie jednej czy drugiej opcji. Nie zawsze łatwo jest je dostrzec, ale cała ich gama jest obecna już w jego najwcześniejszych dziełach. Teksty apostoła Pawła są eksponowane w szczególny sposób ${ }^{60}$, stanowiąc niewątpliwie rodzaj paradygmatu nauczania apostolskiego ${ }^{61}$.

W De principiis i Komentarzu do Rz Orygenes podejmuje dyskusję o wybraniu przez Pana Jakuba przeciwko Ezawowi, kiedy byli jeszcze w łonie swej matki Rebeki (por. Rdz 25,23; Ml 1,2-3) ${ }^{62}$. Z kolei słowa skierowane do Jeremiasza (por. Jer 1,5$)^{63}$, czy dar prorockiego widzenia u Jana Chrzciciela, gdy był jeszcze w łonie swej matki Elżbiety (por. Łk 1,41$)^{64}$ wskazują na Boży wybór niezależnie od zasług człowieka ${ }^{65}$. Pojawiają się jeszcze bardziej dramatyczne przypadki wyłaniające się z kart dziejów zbawienia. Chodzi o faraona, którego serce „Bóg uczynił zatwardziałym" (por. Wj 4,21; 7,3) ${ }^{66}$ i Judasza - zdrajcę Zbawiciela ${ }^{67}$.

60 Por. Rz 9,16; 18-19; 20-21; Fil 2,13 w De principiis III,1,7.

61 Orygenes nie nawiązał do tekstów, które w sposób pozytywny ukazują wolność człowieka, jak Ga 5,1 czy @ Kor 3,17. Por. B.D. Jackson, Sources of Origen’s Doctrine of Freedom, s. 14.

62 Por. M. Harl, La Préexistence des âmes dans l'oeuvre d'Origene, w: taze, Le Déchiffrement du Sens: Études sur l'herméneutique chrétienne d'Origène à Grégoire de Nysse, Paryz 1993, s. $247-268$.

63 „Prorok Jeremiasz, był znany Bogu, «zanim został ukształtowany w łonie matki», i został przez Niego uświęcony, «zanim przyszedł na świat» (por. Jer 1,5.6), oraz chłopcem jeszcze będąc uzyskał łaskę prorokowania”; De principiis III,3,5.

64 „Trzeba zastanowić się nad przyczynami, dla których ludzka dusza raz podlega oddziaływaniu dobrych, a kiedy indziej znowu złych duchów. Przypuszczam, że powody takiego stanu rzeczy są wcześniejsze niż cielesne narodziny, jak widać to po Janie, który podskakiwał $\mathrm{z}$ radości w łonie swej matki, Elżbiety, kiedy do jego uszu dotarły słowa pozdrowienia Maryi”; De principiis III,3,5.

65 Por. A. Monaci Castagno, Elezione, giustizia e libero arbitrio in Origene, Dizionario di spiritualità biblico-patristica, t. 15 (1997), s. 240-241.

66 Por. M. Harl, La mort salutaire du Pharaon selon Origène, w: taze, Le Déchiffrement $d u$ Sens, s. 269-277.

67 Tragiczne dzieje Judasza rzucają cień na rzeczywistą niezależność i wolność wyboru. Orygenes stanął wobec wielkiego problemu: czy przypadkiem nie chodzi tu o jakieś odwieczne przeznaczenie, determinujące grzech zdrady Jezusa. Podobnie, jak przy omawianiu innych kwestii, tak i tu trudno doszukać się jednego, gotowego klucza, pozwalającego na rozwiązanie problemów. Orygenes bowiem rozumie współistnienie Bożej Opatrzności i wolnych wyborów człowieka nie w perspektywie konieczności, ale współpracy. Przede wszystkim więc Aleksandryjczyk stara się odpowiedzieć na pytanie, czy Boża wszechwiedza nie determinowała grzechu zdrady. Omawiając przypadek Judasza (por. Philocalia XXIII) Orygenes zaznacza, że chociaż Jezus wiedział, że zostanie zdradzony, nie oznacza to, że wydarzenie to 
Fragmenty te wskazywały rzekomo na Boga aktywnie działającego nie tylko dla zbawienia, ale wręcz dla zniszczenia człowieka. Fragmenty te rzekomo uzasadniały gnostyckie i marcjonistyczne tezy, które poddawały w wątpliwość istnienie wolnej woli człowieka ${ }^{68}$. Orygenes pisze jednak, że w obu przypadkach należy uznać, iż „woli Boga nikt się sprzeciwić nie może, jednak powinniśmy wiedzieć, że Jego wola jest sprawiedliwa i słuszna. Albowiem od naszej woli zależy, czy jesteśmy dobrzy, czy źli; od woli Boga natomiast zależy, na jaką karę przeznaczony zostaje zły, a do jakiej chwały dobry" ${ }^{69}$. Ponadto, jak wskazuje Adamancjusz w innym miejscu, „przez Mądrość Bożą wszystko na tym świecie zostało tak urządzone, aby nic nie było bezużyteczne u Boga, zarówno zło, jak i dobro [...] Bóg nie stworzył [zła] i choć mógł [go] zakazać [...] używa go do koniecznych celów"70. W podobnych kategoriach Aleksandryjczyk analizuje ogólny problem zła na świecie. Uważa, że należy je pojmować w duchu chrześcijańskim: „Bóg zsyła jakieś zło po to, ażeby nawrócić i uleczyć tych, którzy wymagają takich

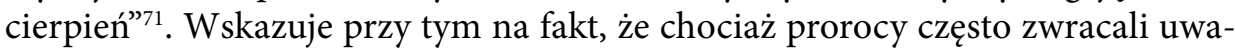
gę na upomnienia i kary pochodzące od Boga, jednak czasami działa On bez pośpiechu, pozwalając na opamiętanie się grzeszników. To decyzja człowieka sprawia, że Bóg podejmuje odpowiednie kroki ${ }^{72}$.

Zagadnienie wolności wyboru jawiło się jako problem metafizyczny, a nie historyczny, gdyż do tego sprowadza się w zasadzie kwestia powiązań pomiędzy powołaniem przez Boga a historią narodu wybranego. Jednak problem wolnej

musiało nastąpić w sposób nieunikniony. Dowodem tego jest kilka proroctw potępiających postępowanie Judasza, gdyby ten zdradził z jakiejś konieczności, gdyby nie miał wyboru, wyrzuty te byłyby bezsensowne. Trzeba zatem przyjąć, że istniała dla niego możliwość pozostania uczniem Jezusa. Człowiek bowiem zawsze ma władzę bycia cnotliwym lub niegodziwym. Komentując Ewangelię św. Jana Orygenes zwraca uwagę na podobne problemy (por. Commentarius in Joh. XXXII,22). Por. G. Lettieri, Origene, Agostino e il mistero di Giuda. Due esegesi di Joh. XIII in conflitto, w: L. Padovese (red.), Atti del V simposio di Efeso su S. Giovanni Apostolo (Turchia: la Chiesa e la sua storia 8), Rzym 1995, s. 169-183; M.I. Danieli, Libertà-liberazione degli scritti di Origene, Dizionario di spiritualità biblico-patristica, t. 37 (2004), s. 244; A. Monaci Castagno, Elezione, giustizia e libero arbitrio in Origene, s. 247.

68 Odnośnie do argumentacji antymarcjońskiej w kwestii wolnej woli człowieka por. M.C. Paczkowski, Kwestia wolnej woli człowieka w polemice antymarcjońskiej Tertuliana, w: G. Kucza, G. Wita, Antropologia miejscem spotkania i dialogu międzyreligijnego (Studia i materiały Wydziału Teologicznego Uniwersytetu Śląskiego w Katowicach 45), Katowice 2008, s. 136-139.

69 Commentarius in Rom. VII,16.

70 Homilia in Numeros XIV,2.

71 Contra Celsum VI,56.

72 Aleksandryjczyk pisze: „Nazywamy Go [= Chrystusa] Lekarzem, to przecież działa On jako lekarz nie wobec wszystkich, lecz jedynie wobec tych, którzy zrozumiawszy swą chorobę uciekają się pod opiekę Jego miłosierdzia, ażeby otrzymać zdrowie”; De principiis II,7. 
decyzji, tak w sferze wspólnotowej, jak i indywidualnej, wiąże się ze sposobem działania Boga. Mimo ścisłej zależności biegu refleksji Orygenesa od myśli Pawłowej $^{73}$ na temat losów Izraela, ma się wrażenie, że egzegeza w De principiis różni się od komentarza do Rz. W swoim dziele egzegetycznym autor aleksandryjski ujmuje fakt niewierności Żydów ${ }^{74}$ i wiary pogan ${ }^{75} \mathrm{w}$ kategoriach paradygmatu postępowania złych i dobrych chrześcijan.

Komentując fragment o zatwardziałym sercu faraona, które staje się takie na skutek Bożej interwencji - doprowadzającej tym samym do śmierci i wydawałoby się ostatecznego potępienia go, Orygenes zwraca uwagę na terapeutyczny aspekt tego stanu ducha.

Ten więc, który [...] zna drogi poszczególnych śmiertelników i wie, jaką drogą powinien również faraona doprowadzić do takiego stanu, ażeby „,rozsławić przez niego imię swoje na całej ziemi" (Rz 9,17) - skarciwszy go najpierw wieloma plagami i zawiódłszy aż do utopienia w morzu. Nie można jednak mniemać, że na utopieniu skończyło się działanie opatrzności Bożej względem faraona: nie wolno nam sądzić, że utonąwszy zginął on od razu substancjalnie. Albowiem jak mówi Pismo: „W ręce Boga i my, i nasze słowa, i roztropność wszelka, i umiejętność działania” $(\operatorname{Mdr} 7,16)^{76}$.

Inne rozwiązanie trudnych problemów teologicznych i egzegetycznych polega na przepracowaniu i pogłębieniu problemu wszechwiedzy jako zasadniczego przymiotu Boga. Do tej zasady odwoływał się już Ireneusz z Lyonu, który w ten sposób poradził sobie $\mathrm{z}$ tymi samymi trudnościami egzegetycznymi ${ }^{77}$. Wyraźnie występuje przy tym przeciwko predestynacji w jej klasycznym ujęciu.

Orygenes kilkakrotnie powraca do analizy Rz 8,28-30, gdyż gnostycka egzegeza uznawała ten fragment za najważniejszy argument wspierający ideę istnienia ludzi z natury samej zbawionych lub potępionych. Aleksandryjczyk zaczyna

73 Por. F. Cocchini, Il Paolo di Origene. Contributo alla storia della recezione delle epistole paoline nel III secolo (Verba Seniorum [nuova serie] 11), Rzym 1992.

74 Żydzi bywają często archetypem przeciwników nauki ewangelicznej, ale ich niewiara polega na tym, że pozostali w sferze cieni i zapowiedzi. To sprawia, że Chrystus ciągle jest „wyszydzany i wydawany”. Autor aleksandryjski przypomina o odrzuceniu Jezusa przez naród wybrany, także mówiąc, że „w Jerozolimie nie miał [On], gdzie złożyć głowy (por. Mt 8,20)”; Commentarius in Matth. XVI,26.

75 Orygenens podkreśla, że „Królestwo Boże” przeszło z Żydów na pogan, którzy uwierzyli w Chrystusa. Por. Commentarius in Joan. X,24,138-140.

76 De principiis III, 1,14 .

77 Np. słowa z Mal 1,2-3 są zupełnie zrozumiałe kiedy uświadomimy sobie, że Bóg wie wszystko, jeszcze zanim się to wydarzy. Por. A. Monaci Castagno, Elezione, giustizia e libero arbitrio in Origene, s. 244. 
od uściślenia, że istnieje następstwo w aktach Boga. Początkiem wszystkiego jest wszechwiedza. Komentując część perykopy Pawłowej zauważa, że Bóg przeznaczył ich dlatego, że obejmuje swoją wszechwiedzą późniejsze wydarzenia:

Zwróćmy uwagę na szyk poszczególnych zdarzeń. Bóg usprawiedliwia kogo przedtem powołał, i kogo nie powołał, tego by nie usprawiedliwił; powołuje zaś tego, kogo przed powołaniem przeznaczył, a kogo nie przeznaczył, tego by nie powołał. Ale przeznaczenie nie jest dla Niego wstępem do powołania i usprawiedliwienia [...], lecz przeznaczenie wyprzedza uprzednia wiedza $\mathrm{Boga}^{78}$.

Dopiero więc po uprzednim poznaniu, Bóg niektórych przeznaczył do bycia podobnymi do „obrazu swego Syna”79. Zna więc On uprzednio postępowanie każdego, co znamienne, zna je nie jako konieczność, ale jako możliwość. W tym miejscu swych rozważań Aleksandryjczyk odnosi się do teorii możliwości ${ }^{80}$ :

Jeżeli w związku z tym ktoś zapyta, czy zdarzenie, którego przebieg Bóg „znał od wieków", może nie mieć miejsca, odpowiemy, iż zdarzenie może nie mieć miejsca, bo chociaż istnieje taka możliwość, nie istnieje konieczność, by zdarzenie nastąpiło lub nie; w żadnym wypadku nie jest ono wynikiem konieczności, lecz może także nie mieć miejsca ${ }^{81}$.

\section{Adamancjusz konkluduje:}

Nie możemy zatem sądzić, że odwieczna wiedza Boża jest przyczyną przyszłych zdarzeń; lecz ponieważ te zdarzenia miały nastąpić na skutek starań działającego człowieka, dlatego Bóg je „znał od wieków”, gdyż „wie On wszystko pierwej, niźli się stanie"s2.

Orygenes zamyka swój wywód dowodami biblijnymi ${ }^{83}, \mathrm{z}$ których wyprowadza wniosek, że jeśli Paweł nie odpowiedziałby w sposób pozytywny na Boże wybranie, mógłby zostać odrzucony przez Boga ${ }^{84}$. W świetle tych uwag można powiedzieć, że wybranie i wynikające $\mathrm{z}$ niego możliwości są konsekwencją

78 Philocalia XXV,2.

79 Por. H. Crouzel, Théologie de l'image de Dieu chez Origène (Théologie 34), Paris 1956.

80 Por. A. Monaci Castagno, Elezione, giustizia e libero arbitrio in Origene, s. 245.

81 Philocalia XXV,2. Tej kwestii dotyczy ważna część Rz. Por. G.B. Caird, Predestination - Romans 9-11, Expository Times 68 (1957), s. 324-327; E. Dinkler, The Historical and Eschatological Israel in Romans Chapters 9-11: A Contribution to the Problem of Predestination and Individual Responsibility, Journal of Religion 36 (1956), s. 109-127; B. Mayer, Unter Gottes Heilsratschluss. Prädestinationsaussagen bei Paulus, Würzburg 1974, s. 167-313.

82 Philocalia XXV,2.

83 Por. 1 Kor 9,16.27.

84 Por. Philocalia XXV,5. 
wszechwiedzy Boga ${ }^{85}$. Wybranie nie jest jednak darmowym aktem łaski, ale wynikiem współpracy między wszechmocną i wszechwiedzącą Opatrznością, a wolnym wyborem jednostki ${ }^{86}$.

U Aleksandryjczyka znajdujemy zbiór prawd chrześcijańskich wyrażonych językiem myśli hellenistycznej. Główne przymioty człowieka, jak wolność i swoboda wyboru znajdują swoje źródło w Chrystusie, który „wyswobodził nas ku wolności”. Jest to o wiele szersza perspektywa niż w klasycznym ideale greckim wolnego mędrca i biblijnego sprawiedliwego, decydującego się iść wiernie drogą Bożych przykazań. Orygenes pisze w Komentarzu do Rz:

Paweł [apostoł] ukazuje, że posiadamy wolność wyboru. To z nas pochodzi to, że stajemy się posłuszni sprawiedliwości, albo grzechowi [...]. Powinniśmy pamiętać o tym], aby niepotrzebnie nie narzekać na przyczynę grzechu: że to diabeł, albo zniewalające pęta natury, fatalne warunki lub bieg gwiazd sprawiają, że grzeszymy... Można odszukać tego, który wyzwala z grzechu. Jezus [...] rzekł do żydów: „Jeżeli będziesz trwać w nauce mojej, będziecie prawdziwie moimi uczniami i poznacie prawdę, a prawda was wyzwoli” (J 8,31-32) [...]. Istnieje wolność godna potępienia i służba godna pochwały. Bowiem czuć się wolnym wobec sprawiedliwości to przewinienie, a być jej sługą to powód do chwały ${ }^{87}$.

W traktacie De principiis fatalistyczny sposób rozumowania autor przypisywał "prostaczkom (simpliciores)" "88 Jednak w tamtym kontekście Adamancjusz negował tego typu przekonania, ukazując, że człowiek popełnia grzeszne uczynki z własnej woli, a dopiero po jakimś czasie tę skłonność umacniają demoniczne siły zła. Jest więc prawdopodobne, że także w komentarzu do Rz $6,16^{89}$ jego intencją było skorygowanie fatalistycznych przekonań tych chrześcijan, których zwano „prostaczkami” Orygenes powraca jeszcze do tej polemiki w interpretacji $\mathrm{Rz} 6,19$, lecz tym razem celem jego ofensywy stają się gnostycy ${ }^{90}$.

$\mathrm{W}$ tej samej perspektywie, ale $\mathrm{z}$ odniesieniem do tego, co przydarzyło się duszom przed wejściem do obecnego świata, a więc w sferze preegzystencji, zo-

85 Por. C. Micaelli, Prescienza divina e libero arbitrio nel "Commento" origeniano "alla Lettera ai Romani": Osservazioni su alcune implicazioni filosofiche, w: L. Perrone (wyd.) P. Berardino i D. Marchini (współpraca), Origeniana Octava: Origen and the Alexandrian Tradition. Papers of the 8th International Origen Congress, Pisa, 27-31 August 2001, tom 1, Piza 2001.

86 Por. A. Monaci Castagno, Elezione, giustizia e libero arbitrio in Origene, s. 247.

87 Commentarius in Rom. VI,3;5;7.

88 Por. De principiis III,2,1.

89 Por. Commentarius in Rom. VI,3. Odnośnie do tego wersetu Orygenes zauważa, ze sposób wyrażania się Apostoła nie jest jasny. Por. F. Cocchini, Commento alla lettera ai Romani, tom 1, s. 307-308.

90 Por. Commentarius in Rom. VI,4. 
staje wyjaśniony wybór Jakuba, a także Pawłowa interpretacja tego wydarzenia (por. Rz 9,20-24) ${ }^{91}$.

\begin{abstract}
Albowiem Stwórca nie czyni „naczyń zaszczytnych” i „naczyń niezaszczytnych” od początku, wedle swej znajomości rzeczy przyszłych, ponieważ na jej podstawie ani nie potępia naprzód, ani nie usprawiedliwia, lecz „naczyniami zaszczytnymi” czyni tych, co się oczyścili, a „naczyniami niezaszczytnymi” tych, co zaniedbali oczyszczenia. Toteż z przyczyn, które wyprzedzają stworzenie „naczyń zaszczytnych” i „niezaszczytnych”, jeden człowiek jest przeznaczony, aby zażywał chwały, a drugi, aby doznał hańby. Jeśli raz przyjmiemy, że pewne dawniejsze przyczyny powodują „naczynie zaszczytne” i „naczynie niezaszczytne”, to czyż - wracając do zagadnienia duszy - niedorzecznością będzie sądzić, że miłość do Jakuba, a nienawiść do Ezawa miały swoje uprzednie przyczyny, że Jakub był kochany, zanim przybrał ciało, a Ezaw był znienawidzony, zanim znalazł się w łonie Rebeki? ${ }^{92}$.
\end{abstract}

Teoria o preegzystencji tłumaczy więc problem Bożego wybrania w tych trudnych dla Orygenesa biblijnych fragmentach ${ }^{93}$ :

A co się tyczy ludzi: czyż można uznać, że wraz z ciałem została ukształtowana dusza tego, który „w łonie matki oszukał swojego brata”, to znaczy dusza Jakuba (por. Rdz 1, 16)? Czy wraz z ciałem została utworzona lub ukształtowana dusza tego, kto „przebywając jeszcze w łonie matki został napełniony Duchem Świętym” (por. Łk 1,41)? Mam tu na myśli Jana, który cieszył się i niezmiernie radował w łonie rodzicielki, ponieważ do uszu jego matki, Elżbiety, dotarło pozdrowienie Maryi. Czy wraz z ciałem została utworzona i ukształtowana również dusza tego człowieka, który, jak powiedziano, „zanim został ukształtowany w łonie, był znany Bogu” i zanim „przyszedł na świat, został przez Niego uświęcony” (por. Jer 1,5)? Chodzi o to, żeby się nie wydawało, iż Bóg napełnia kogoś Duchem Świętym nie wedle wyroku i zasług i uświęca bez zasługi ${ }^{94}$.

Odwołanie się do ulubionej teorii by uratować wizerunek Boga sprawiedliwego i respektującego wolne wybory człowieka, to typowy ruch w myśli Orygenesa. $\mathrm{W}$ ten sposób radzi sobie $\mathrm{z}$ nieortodoksyjnymi interpretacjami wspomnianych fragmentów biblijnych.

Ze względu na specyfikę komentarzy biblijnych, refleksje Orygenesa mają swobodniejszy charakter. Egzegeta e dużej mierze był wolny od konieczności polemiki widocznej w De principiis. Apologetyka w komentarzu biblijnym łą-

91 Por. M. Reasoner, Romans in Full Circle. A History of Interpretation, Louisville 2005, s. $105-106$.

92 De principiis III,1,20-21.

93 Por. A. Monaci Castagno, Elezione, giustizia e libero arbitrio in Origene, s. 242.

94 De principiis I,7,4. 
czy się z troską duszpasterską, co charakteryzuje ostatnie z dzieł tworzonych przez wielkiego Aleksandryjczyka ${ }^{95}$. Tak więc problematyka egzegetyczna nie jest wyłączna, bowiem Orygenes stara się wniknąć jak najgłębiej w tekst apostoła i odkryć harmonię Rz 9 z całym listem. Ten aspekt wydaje się wart podkreślanie ze względu na wagę problematyki i rozległość dygresji, które nieustannie przerywają tok analizy tekstu. Analiza poszczególnych słów i zwrotów użytych przez św. Pawła, pociąga za sobą potrzebę przywoływania coraz to innych perykop biblijnych. W ten sposób pole analizy interpretacyjnych znacznie się rozszerza. Taki sposób lektury daje wrażenie, że komentarz Orygenesa nie jest jednorodny i stanowi nawarstwienie kwestii ze Starego i Nowego Testamentu. Jednak dokładniejsza analiza ujawnia, że wyczulenie filologiczne oraz zmysł teologa pozwalają na nowo łączyć poszczególne wątki refleksji w harmonii z tematyką poszczególnych części $\mathrm{Rz}^{96}$.

Kontekst tematyczny, w którym Orygenes odwołuje się do kwestii wolnej woli można łatwo zidentyfikować dzięki dwom inkluzjom, które sam wskazuje: pierwsza, mająca dosyć szeroki charakter, to rozdziały 9-11, a druga dotyczy Rz 9,6-21. Rz 9,1 to oznaczenie głównego tematu: problemu zbawienia Izraela ${ }^{97}$. Druga inkluzja jest bardziej wyostrzona. Zanim Orygenes rozpocznie komentarz do $\mathrm{Rz} 9,14-19^{98}$, nawiązuje do tej perykopy we wcześniejszym rozdziale swego komentarza. Adamancjusz, odwołując się do Rz 9,6-1399, widzi w przykładach wolnego wyboru Boga oraz w wywyższenia Izaaka i Jakuba rysujące się sprzeczności z dalszą częścią Pawłowego wywodu. W odróżnieniu do De principiis, gdzie Orygenes analizuje oddzielnie każdy $\mathrm{z}$ wersetów, w komentarzu biblijnym egzegeta aleksandryjski konfrontuje dwie perykopy $\mathrm{w}$ ich pełnym brzmieniu. Chodzi o Rz 9,14-19 i 9,20-21. Dopiero później komentator wchodzi w zagadnienie wolnej woli.

W kontekstach egzegetycznych problem ten jest rozwijany czasami w nieco odmienny sposób i na bazie zróżnicowanego wyboru tekstów. Jest to uzasadnione potrzebami polemiki, w której jedne wątki należało pominąć, aby rozwinąć inne, często ważniejsze. W każdym razie takie postępowanie usprawiedliwia „jedność metody i myśli" ${ }^{100}$.

Pierwszy tekst, który wymagał wyjaśnienia, to Rz 1,24, gdzie Apostoł występuje przeciwko poganom, których „wydał Bóg poprzez pożądania ich serc na

95 Por. R. Girod, Origène. Commentaire sur l'Évangile selon Matthieu (Livres X et XI), tom 1 (SC 162), Paris 1970, s. 14-18.

96 Wyraźnie widać to, gdy Orygenes łączy część dotyczącą pouczeń moralnych

(Rz 12-14) z poprzednimi sekcjami.

97 Por. Commentarius in Rom. VII,13.

98 Kwestią Rz 9,16-19 zajmuje się M. Reasoner, Romans in Full Circle, s. s. 95-96.

99 Por. Commentarius in Rom. VII,16.

100 E. Junod, Origène. Philocalie, s. 9. 
łup nieczystości, tak iż dopuszczali się bezczeszczenia własnych ciał”. Zdanie to wydaje się całkowitym usprawiedliwieniem dla grzeszników ${ }^{101}$. Problematyczny werset stał się obiektem zainteresowania Orygenesa w traktacie $O$ modlitwie, napisanym około 233-234 roku ${ }^{102}$. Wezwanie „I nie wódź nas na pokuszenie” zostało odczytane w świetle obszernego cytatu Lb 11, opisującego przesyt i szemranie Izraela $\mathrm{z}$ powodu mięsa przepiórek ${ }^{103}$. Na podstawie tego marginalnego epizodu biblijnego Adamancjusz rozwija obecny w De principiis motyw ostrzeżenia ${ }^{104}$, „ażeby nigdy nie ogarnął nas przesyt dobra; przeciwnie, im więcej otrzymujemy z tego szczęścia, tym bardziej powinno się w nas rozszerzać i powiększać jego pragnienie" ${ }^{105}$. W rozważaniach egzegetycznych o $\mathrm{Rz}$ argumentacja jest zupełnie inna. Orygenes podkreśla, że Rz 1,24 stanowi problem dla marcjonitów, którzy w Bogu Starego Testamentu dostrzegali wyłącznie surowego sędziego ${ }^{106}$. Przechodzi następnie do kwestii stawianych przez wiernych i jego

101 Por. Commentarius in Rom. I,18. Przed Orygenesem żaden z autorów nie cytował tego wersetu.

102 Por. De oratione XIX,12-16. To pierwszy komentarz erudycyjny, egzegetyczny i teologiczny do modlitwy „Ojcze nasz”. Dzieło, napisane na życzenie dwóch przyjaciół chrześcijan, przesiąknięte jest nie tylko wątkami spekulatywno-filozoficznymi, lecz także troską o bogatych i wykształconych członków Kościoła aleksandryjskiego.

103 Według Orygenesa Bóg daje nie tylko „wszystkim istotom żyjącym i rozumnym zmysłowość i zdolność myślenia, lecz niektórym udziela nawet wrażliwości i inteligencji doskonałej. Słusznie zatem ci ludzie, którzy odeszli od Boga, zostali z kolei przez Niego opuszczeni”. W ten sposób otrzymują „dobrodziejstwo oczyszczania ze zła, które towarzyszy błędowi... Oni dobrowolnie poddadzą się tym próbom, znienawidzą swego przewrotnego ducha. Bóg bowiem nie chce narzucać dobra, On pragnie istot wolnych. Z powodu poddania się złu niektórzy prawie już go się nie wstydzą, a jeśli je oddalają, to dlatego, że pomylili je z dobrem... Słusznie Bóg prowadzi nas w pułapkę, zgodnie ze słowem: «Pozwoliłeś nam wejść w pułapkę» (Ps 66,11). Nawet najmniejszy z ptaków, wróbel, nie wpada w pułapkę bez woli Ojca; jeśli w nią wpadł, to dlatego, że źle posługiwał się skrzydłami, które powinny go unosić w powietrzu. W naszej modlitwie zatem prosimy, by nie czynić niczego, co mogłoby nas prowadzić na pokuszenie poddane sprawiedliwemu osądowi Boga; dzieje się to $\mathrm{z}$ tymi wszystkimi, których opuszcza Bóg, zgodnie z pożądliwościami ich serca, wydaje na łup nieczystości, bezwstydnych żądz, ich wypaczonym sądom, na popełnianie tego, czego czynić nie wolno... Jednak pokusa służy czemuś. Wszyscy poza Bogiem, także nie wyłączając nas, nie znają tego, co nasza dusza otrzymała od Boga. I oto pokusa odsłania nam, pozwala nam odkryć naszą nędzę i przymusza nas do uznania tych wszystkich dóbr, o których pokusa uświadamia nas, że jesteśmy w ich posiadaniu”. De oratione XIX,14-15.

104 Por. De principiis III,1,12-13; IV,4,3. Orygenes cytuje Rz 1,24 także w Contra Celsum $\mathrm{V}, 32$.

105 De principiis I,3,8. Por. J. Daniélou, Messaggio evangelico e cultura ellenistica, Bolonia 1975, s. 448.

106 Por. Commentarius in Rom. I,18; J. Ramon Diaz-Cid, Justicia, pecado y filiación. Sobre el Comentario de Origenes a los Romanos, Toledo 1991, s. 26. 
samego. Orygenes znajduje rozwiązanie w strukturze człowieka obdarzonego ciałem duszą i duchem, nawiązując do Pawłowej trychotomii. W duszy należy szukać wolnej woli. Zresztą ten element struktury człowieka objawia się dzięki myśli i wolnemu działaniu ${ }^{107}$. To dzięki zdolności decydowania, dusza ${ }^{108}$ będąc pomiędzy ciałem a duchem, wybiera swoją drogę. Gdy więc wybiera ciało, człowiek staje się „chorym na duszy”109, a wszystkie dobra ducha go opuszczają ${ }^{110}$. Tak więc obok elementu decyzji i wolnej woli Orygenes wprowadza konieczności bolesnej kary, aplikowanej dla dobra człowieka ${ }^{111}$. Pojawia się jednak przekonanie, że to nie Bóg wystawia duszę na ciężkie doświadczenia, jak sugeruje tekst Apostoła, lecz „dobre siły” umysłu. Następuje więc przesunięcie akcentu ze sposobu działania Boga na odpowiedzialność człowieka, który w niewłaściwy sposób używa wolnej woli ${ }^{112}$.

Kolejnym tekstem z Rz, który skłania Orygenesa do refleksji nad wszechmocą Stwórcy a wolnością stworzenia jest Rz 6,9. Św. Paweł ogłasza niemożność powtórzenia odkupieńczej ofiary Chrystusa ${ }^{113}$. Autor komentarza do Rz występuje przeciwko zwolennikom metensômatôsis ${ }^{114}$, którzy zakładali konieczność powtarzania dzieła odkupienia ze względu na działanie mechanizmu wolnego wyboru także po śmierci, a więc i możliwości grzechu. $\mathrm{Z}$ tego względu rodziła się potrzeba „udzielania lekarstwa Chrystusowego" ${ }^{115}$. By wyrwać człowieka z błędnego koła skłonności do zła Aleksandryjczyk głosi prymat miłości według nauki 1 Kor 13,8 ${ }^{116}$ Przez zjednoczenie ze Zbawicielem bojaźń sługi zostaje przezwycię-

107 Por. A.-G. Hamman, L’homme image de Dieu, Paryż 1987, s. 89.

108 Tertulian określa duszę jako „wolną w wyborze”. Na podstawie jej reakcji na czynniki zewnętrzne wnioskuje się, że posiada ona „moc kontroli” i „swobodę wyboru”. Por. De anima 22 i 24.

$109 \mathrm{Na}$ Hipokratejskiej nauce o zróżnicowaniu środków terapii Orygenes opiera swoje rozważania w De principiis XI,7 i Homiliae in Num. 21,1. Wyd. krytyczne homilii o Lb w: A. Méhat, Origène. Homélies sur les Nombres (Sources Chrétiennes 29), Paryż 1951; przekład w: S. Kalinkowski (tłum. i oprac.) - W. Stanula (wstęp), Orygenes. Homilie o Księgach Liczb, Jozuego i Sędziów (Pisma Starochrześcijańskich Pisarzy 34), z. 1-2, Warszawa 1986.

110 Commentarius in Rom. I,18.

111 Powyższe kwestie zostają rozwinięte w: De principiis III,1,8-9; Commentarius in Rom. VIII,11-13; IX,2; Philocalia 21-27.

112 F. Cocchini, La „quaestio” sul libero arbitrio e l'interpretazione origeniana di Rm 9 nel Commento alla Lettera ai Romani, w: L. Perrone (red.), Il cuore indurito del Faraone, s. 108.

113 Por. Commentarius in Rom V,10.

114 Orygenes przypisuje tę naukę Bazylidesowi lub bliżej nieokreślonym heretykom. Por. Commentarius in Rom. V,10, De principiis I,8,4; Contra Celsum I,13; IV,17; V,49; VIII,30; Commentarius in Mt X,20; XI,17; Commentarius in Joh. VI,64.

115 Commentarius in Rom. V,10.

116 Por. Commentarius in Rom. V,10. 
żona przez miłośćc ${ }^{117}$. Chrześcijanin w bojaźni jest przybity razem z Chrystusem do krzyża, w miłości powstaje razem z Nim z martwych. U Orygenesa zostaje podkreślone rozróżnienie pomiędzy pełną obaw postawą niewolniczą, a nastawieniem synowskim czyli postępowaniem przepełnionym miłościąa18. Miłość zdobywa przewagę nad wolnością, gdyż człowiek poznaje dogłębnie paradygmat Bożej miłości, a wylanie Ducha Świętego przekształca radykalnie człowieka ${ }^{119}$. Argumentacja, bazująca na wersetach biblijnych, ma charakter bardziej teologiczny aniżeli filozoficzny. Aleksandryjczykowi udaje się nie tylko zbić argumenty zwolenników metensômatôsis ${ }^{120}$, ale także stoików oraz radykalne rozgraniczenie kategorii osób głoszone przez gnostyków ${ }^{121}$. Z koncepcją niezmienności bytów Orygenes podejmuje polemikę nawiązując do tajemnicy wybrania Izraela (por. Rz 11,16-24) ${ }^{122}$. Wywód Apostoła, jego zdaniem, uwydatnia zarówno odpowiedzialność osobistą, jak i możliwość zmiany swego przeznaczenia po śmierci. Jest to w zasadzie synteza tego, co Aleksandryjczyk wcześniej opisał odnośnie tej kwestii, nawiązując do stoików (una natura omnium rationabilium), która

117 „Nie tylko bojaźń, lecz również miłość może być przyczyną niewoli”; Homilia in Ps 2,11 .

118 „Odróżniamy bojaźń od miłości i mówimy, że miłujący jest doskonalszy od pełnego bojaźni, oraz że bojaźń jest koniecznym wprowadzeniem do miłości. Gdzie zaś wkroczy «doskonała miłość, usuwa lęk» (por. $1 \mathrm{~J}$ 4,18). Ponieważ więc sprawiedliwy jest ukrzyżowany... Kiedy natomiast przyjdzie doskonała miłość, zostaje zdjęty z krzyża, zostaje pogrzebany i wskrzeszony z martwych, aby kroczyć w nowym życiu już nie w bojaźni, lecz w miłości, która jest w Chrystusie Jezusie"; Homilia in Ps 118,120.

119 Por. Commentarius in Rom. V,10.

120 Na podstawie De principiis I,8,4 św. Hieronim niesłusznie przypisuje ten błąd Orygenesowi (por. Epistula 124,3-4).

121 Walentyn, w swojej bardzo rozbudowanej kosmologii obejmującej rozległą hierarchię różnych bytów, opisuje trzy rodzaje dusz. Pierwszy rodzaj to pneumatycy czyli istoty współistotne z eonami, które zaludniają sferę Pleroma. Pneumatycy cieszą się nieodwołalnym przywilejem pewności zbawienia, do którego są predestynowani. Drugim rodzajem dusz, a zarazem przeciwieństwem pneumatyków są hylicy - istoty materialne, bądź choicy - istoty ziemskie, należące do „władcy tego świata” - diabła. Ten drugi rodzaj dusz nieuchronnie skazany jest na potępienie. Pomiędzy tymi dwoma grupami znajdują się psychicy, ludzie zmysłowi wg 1 Kor 2,14, którzy w zależności od swego postępowania dostępują zbawienia w „stanie pośrednim" lub potępienia razem z hylikami. Orygenes nie godzi się na taką kosmologię, w której dusze są predestynowane do zbawienia lub potępienia, lecz ukazuje idee pierwotnej równości wszystkich stworzeń rozumnych (m.in. przez teorię o preegzystencji dusz). Por. W. Quisel, Gnoza, Warszawa 1998; W. Myszor, „Anapausis” w teologii chrześcijańskiej gnostyków (Studia Antiquitatis Christianae 5), Warszawa 1984.

122 Na temat egzegezy gnostyckiej Rz 11,16 por. A. Orbe, Cristología gnóstica. Intoducción a la soteriología de los siglos II y III (Biblioteca de Autores Cristianos 385), Madryt 1976, s. 372 . 
przybiera odmienną formę w zależności od ukierunkowania indywidualnej wolności i własnej decyzji bytów ${ }^{123}$. Orygenes zwraca uwagę nie tylko na ten fakt, ale także na wpływ, jaki wywiera na decyzję człowieka "element zewnętrzny” 124 . Obok demonów pojawiają się aniołowie ${ }^{125}$, opiekujące się ludźmi i stymulujące ich wybór dobra.

W odniesieniu do oddziaływania rozumnej natury, należy użyć słów Apostoła: „O głębokości bogactw, mądrości i wiedzy Boga! Jakże niezbadane są Jego wyroki i nie do wyśledzenia Jego drogi!” (Rz 11,33). W ten sposób zatem każdy, zależnie od swej wolnej woli, staje się szlachetnym drzewem oliwnym albo dziczką oliwną, należy albo do ludu izraelskiego, albo do innego nagannego $\operatorname{rodu}^{126}[\ldots]$. Ponieważ jednak, jak stwierdziliśmy, natura ta zawsze dysponuje wolną wolą, to skoro ktoś należy do rodu izraelskiego i jest gałązką szlachetnej oliwki, może popaść w niedowiarstwo i zostać złamany. A znów ktoś inny, kto wybrał przynależność do nagannego i grzesznego ludu i wskutek tego nosił miano gałązki dziczki oliwnej - jeśli nawróci się ku wierze (ma wszak wolną wolę, dzięki której może się nawrócić ku dobru), dzięki wierze zostaje wszczepiony $\mathrm{w}$ szlachetne drzewo oliwne, zjednoczony $\mathrm{z}$ korzeniem i czerpie soki oliwne ${ }^{127}$ [...]. [Ja sam] nie znam innego świętego korzenia ani świętych pierwocin poza naszym Panem. On bowiem jest pierwocinami wszystkiego $^{128}[\ldots]$. Otóż w ten korzeń wszczepiony jest każdy, kto dostępuje zbawienia, i dzięki temu świętemu zaczynowi zostaje uświęcone całe ciasto rodzaju ludzkiego; i istotnie, niczym święty korzeń dostarcza on soku świętości trwającym w nim gałęziom, gdy przez święte go Ducha swe go ożywia tych, którzy są z Nim ściśle związani, kształtuje słowem, ukwieca mądrością i sprawia, że przynoszą obfite owoce w pełni wszelkich cnót ${ }^{129}$.

Mimo ukierunkowania interpretacji w stronę sfery indywidualnej, Orygenes nie zapomina, iż tematem wiodącym $\mathrm{Rz}$ 9-11 jest kwestia dwóch narodów: Żydów i pogan w Bożym planie zbawienia.

123 Por. Commentarius in Joh. XIII,21.

124 Por. De principiis III,2,4.

125 Ogólny obraz angelologii Orygenesa daje C. Blanc, L’angélologie d'Origène, Studia Patristica, 14 (1976), s. 79-109; M.C. Paczkowski, Aniołowie w starożytnej literaturze chrześcijańskiej (II-IV wiek), w: J. Ługowska, J. Skawiński (red.), Anioł w literaturze i kulturze, Wrocław 2004, s. 42-45. Bardziej specyficzne kwestie rozpatruje M. Simonetti, Due note sull'angelologia origeniana, Rivista di Cultura Classica e Medievale 4 (1962), s. 165-208.

126 Orygenes przywołuje Ps 58 (57),4; Ef 2,12 i Ps 22 (21),11.

127 Aleksandryjczyk zauważa, że „korzeniem tym jedni nazywają Abrahama, inni Seta, jeszcze inni umieszczają w tym miejscu któregoś z dobrze zasłużonych przodków".

128 Cytat z Kol 1,15.

129 Por. Commentarius in Rom VIII,11. Fragment kończy werset Ps 52(51),10): „Ja zaś jak oliwka, co kwitnie w domu Bożym". 
Można zaobserwować, że w wielu punktach komentarza, gdzie tekst biblijny sugeruje problem wolnej woli ${ }^{130}$, Orygenes nie unika rozwijania tej kwestii. Podobnie jest w przypadku Rz 9,16-21, choć zastanawia się nad sposobem formułowania myśli przez apostoła Pawła ${ }^{131}$ i nad wskazaniem na osobę mówiącego (sam apostoł lub jego oponenci) ${ }^{132}$. Jest to skuteczny sposób rozwiązywania niekoherencji tekstowych ${ }^{133}$. Cechą języka używanego przez apostoła jest enigmatyczność i liczne braki formalne. Jest to spowodowane tym, że nie chce i nie może on wyjawić całej tajemnicy Bożej, którą zresztą poznaje tylko częściowo ${ }^{134}$. Tekst Pawłowy przypomina królewski pałac o wielu bramach, przez które wchodzi się i wychodzi. To wyraziste porównanie obrazuje bogactwo tekstu i tajemniczość jego znaczenia. Przewodnikiem jest apostoł, bo sam jako pierwszy doń wszedł ${ }^{135}$. Natomiast

Kto [...] nazbyt zuchwale i niestosownie wdziera się do komnaty owej tajemnicy, Apostoł występuje z okrzykiem bardzo słusznej nagany i powiada: „Człowiecze! Kimże ty jesteś, byś mógł się spierać z Bogiem” (Rz 9,20). Sens tego zdania jest taki:

130 Chodzi o Rz 11,28-36 (por. Commentarius in Rom. VIII,13) i Rz 12,4-5 (por. tamże IX,2)

131 Por. Commentarius in Rom. VII,16.

132 Nie wydaje się to jednak czystym przykładem prozopologii (por. przede wszystkim Philocalia VII, 1;2). Orygenes stosował egzegezę typu prozopograficznego, rozróżniając osobę mówiącego, przy czym szczególne znaczenie miały wyrażenia typu „ex persona Dei”. Por. M.J. Rondeau, Les Commentaires Patristiques du Psautier (IIIe-Ve siècle), I Les travaux des Pères Grecs et Latins sur le Psautier. II Exégèse prosopologique et théologie (Orientalia Christiana Analecta 224), Rzym 1985, s. 223-321.

133 Metoda stosowana jest nie tylko w stosunku do Rz 9,20-21, lecz również $2 \mathrm{Tm}$ 2,20-21. O tym zagadnieniu pisze następująco: „Mówiliśmy już kilkakrotnie o niezręcznych wypowiedziach Apostoła i o ich błędach... Słowa rozpoczynające rozdział: «Jeśli zaś Bóg chcąc», nie mają żadnego zakończenia, tak jak na przykład winnym miejscu powiedział: «Jeśli zaś zaczyn jest święty, to i ciasto» (Rz 11,16); tutaj nie dodał nic podobnego, lecz pozostawił spójnik jakby w zawieszeniu. Gdyby spójnik ten nie został użyty, sens wypowiedzi bez niego byłby jaśniejszy; moglibyśmy na przykład odczytać to zdanie tak: «Bóg, chcąc okazać gniew i dać poznać swą potęgę, znosił z wielką cierpliwością naczynia gniewu; gotowe na zagładę, żeby dać poznać bogactwo swej chwały w naczyniach miłosierdzia»"; Commentarius in Rom. VII,18.

134 Por. Commentarius in Rom. V,1. Por. F. Cocchini, Il linguaggio di Paolo „servo fedele e prudente” nel Commento di Origene alla lettera ai Romani, Studia Patristica 18/3 (1989), s. 355-364. taże, Origene interprete del linguaggio di Paolo nel Commento di Origene alla lettera ai Romani. Problemi esegetici e storici, Annali di storia dell'esegesi 1 (1984), s. 109-128.

135 „Jak w jakimś pałacu królewskim, w którym wiele jest wejść i wyjść, można przechodzić z jednej do drugiej komnaty w taki sposób, że ledwie widać ślady osoby, która wchodzi lub wychodzi: tak samo wydaje się, że Paweł zaledwie. uchyla drzwi tajemnic Bożych, ale nie otwiera ich szeroko"; Commentarius in Rom. VII,16. Porównanie to zostało zastosowane wcześniej w tamże V,1. 
Kimże jesteś ty, który wdzierasz się do komnaty królewskiej i ośmielasz się wciskać w tajemnice wewnętrznej alkowy? A zatem i my zatrzymujemy swoje kroki, tak jakbyśmy znaleźli się w komnacie królewskiej: powiemy tylko kilka zdań, wiele zaś pominiemy milczeniem, powoławszy sobie apostoła Pawła na nauczyciela i przewodnika w tej drodze. Apostoł zatem mówi w imieniu swego oponenta: „Czyżby Bóg był niesprawiedliwy?” i od razu odpowiada: „Żadną miarą!”; chodzi o to, abyśmy wiedzieli, że na wszystkie pozostałe możliwe zarzuty oponenta Apostoł odpowiada zawsze: „Żadną miarą!”136.

Po wprowadzeniu Orygenes prezentuje parafrazę całej perykopy. To dosyć częsty zabieg mający na celu objaśnienie tekstu wyłącznie na bazie syntaktycznej i literackiej. Dopiero o tym etapie może nastąpić lektura alegoryczna i ducho$\mathrm{wa}^{137}$. Adamancjusz wprowadza przeciwnika w dyskusji o kwestii wolnej woli. Aleksandryjczyk uważa, że nie tylko Rz 9,19 to zdanie oponenta apostoła, lecz również cała poprzednia wypowiedź to zagadnienie postawione św. Pawłowi ${ }^{138}$. Według sugestii tekstu komentarza do Rz, to właśnie „oponent” wysuwa argumenty przeciwko wolnej woli człowieka. W dużej mierze jest to streszczenie poglądów gnostyków, głoszących naukę o nieodmiennym przeznaczeniu człowieka do zbawienia lub potępienia ${ }^{139}$.

Oponent [...] powołuje się na słowa przytoczone przez Mojżesza, [a] które skierował do niego Bóg: „Zlituję się nad tym, nad kim się lituję, i okażę miłosierdzie temu, nad kim się zlituję (Wj 33,19). A jeśli tak, to - powiada - zbawienie nie należy do tego, kto chce lub się o nie ubiega, lecz do tego, komu Bóg okazuje miłosierdzie. Wszak - powiada oponent - również faraonowi powiedziano: „Po to właśnie cię wzbudziłem, aby okazać na tobie moją potęgę i żeby rozsławiło się imię moje po całej ziemi (Wj 9,16)"; a powiedziano tak po to, aby się okazało, że jeśli faraon został wybrany w tym celu, żeby na nim moc Boża objawiła się ludziom, to nie od jego woli zależało to, że zginął. I na końcu dodaje: „A zatem komu chce, okazuje miłosierdzie, a kogo chce, czyni zatwardziałym”. Twierdzenie twoje, oponencie, prowadzi do wniosku, że Bóg bezpodstawnie czyni wyrzuty i oskarża ludzi. Jeżeli bowiem Bóg wybiera, kogo chce, i odrzuca, kogo chce, to któż może sprzeciwić się woli Tego, przez którego wszystko się stało? Ów wywód oponenta zmierza do tego, że człowiek nie ma wolnej woli i że nie leży w jego możliwości, aby się zbawił lub został potępiony [...]. Wypowiedź: „[Zbawienie] nie zależy od tego; kto chce albo się o nie ubiega, ale od Boga, który okazuje miłosierdzie” rozumiemy podobnie jak zdanie, Dawida zapisane w Psalmie: „Jeżeli Pan domu nie zbuduje, na próżno się

136 Commentarius in Rom. VII,16.

137 Por. Commentarius in Rom I,16, IV,1.

138 Por. Commentarius in Rom. VII,16. Interpretacja Orygenesa zostaje podjęta przez Hieronima, który po części z nią polemizuje. Por. Epistula 120,10.

139 Problematykę tę rozwija C. Rabinowitz, Personal and Cosmic Salvation in Origen, Vigiliae Christianae 38 (1984), s. 322-324. 
trudzą ci, którzy go wznoszą. Jeżeli Pan miasta nie ustrzeże, strażnik czuwa daremnie" (Ps 127,1). Nie zaleca tutaj, aby budowniczy domu nic nie robił i był bezczynny, bo Pan i tak dom zbuduje; przeciwnie - budowniczy powinien dokładać starań i wysiłku na miarę ludzką, jednakże zasługą Boga jest, że po usunięciu wszelkich przeszkód dzieło dochodzi do skutku. Skoro więc tekst ten poucza nas, że człowiek dokłada wysiłku i starania, Bóg zaś doprowadza dzieło do skutku i urzeczywistnienia, zatem rzeczą uczciwą i pobożną będzie przypisanie człowiekowi pracy, którą wykonał, efektu zaś tej pracy raczej Bogu niż człowiekowi ${ }^{140}$.

Jest to zupełnie nowy punkt widzenia w stosunku do De principiis, gdzie nasz autor sugeruje, że to sam apostoł odpowiada na swoje wątpliwości ${ }^{141}$. Dla Orygenesa obecna sytuacja stworzenia zarówno pogrążonego w niewoli, jak pragnącego wyzwolenia, uzależniona jest od wolnej woli bytów zharmonizowanej $z$ opatrznościowym działaniem Boga ${ }^{142}$.

Odnośnie do Rz 9,22-26 Orygenes pisze: „Wydaje się, iż tekst ten można rozumieć w takim sensie, że Bóg daje poznać swoją cierpliwość i potęgę przez to, że cierpliwie znosi niedowiarków i niewierzących: cierpliwość, gdy długo znosi, bo Może się opamiętają i nawrócą; potęgę - gdy niekiedy karci i nie zawsze pozostawia występki bez kary" ${ }^{143}$. Dotyczy to perykopy Wj 4,21, która przywoływali gnostycy dla uzasadnienia tezy o złym demiurgu ${ }^{144}$. Komentarz egzegetyczny daje szerszą perspektywę.

Serce faraona zaś było utwardzone w taki oto sposób: Bóg nie chciał wywrzeć na nim nagłej i pełnej pomsty; choć bowiem nieprawość faraona była pełna, to jednak i jemu Bóg w swej pobłażliwości nie zabrał możliwości poprawy, dlatego z początku wymierzał łagodniejsze ciosy, które z wolna stawały się coraz cięższe ${ }^{145}$. Cierpliwość Boga utwierdzała faraona w arogancji; gromadził więc w sobie coraz większy gniew, tak iż do niego można odnieść słowa zapisane przez Apostoła: „A może gardzisz bogactwem dobroci, cierpliwości i wielkoduszności Jego, nie chcąc wiedzieć, że dobroć Boga chce cię przywieść do nawrócenia? Oto przez zatwardziałość swoją i serce nieskłonne do nawrócenia skarbisz sobie gniew na dzień gniewu” ( $R z$ 2,4-5). A zatem to nie Bóg czyni zatwardziałym kogo chce, lecz zatwardziałym sam się czyni ten, kto

140 Commentarius in Rom. VII,16.

141 Por. II,9,7.

142 Por. G. Sfameni Gasparro, Caduta, w: A. Monaci Castagno (red.), Origene. Dizionario, s. 50 .

143 Commentarius in Rom. VII,18.

144 Por. J. Rius-Camps, Origenes y Marción. Caracter preferentemente antimarcionita del prefacio y del segundo ciclo del Peri Archon, w: H. Crouzel-G. Lomiento, J. Rius-Camps (wyd.), Origeniana, Premier colloque international des études origéniennes, Bari 1975, s. 297-312.

145 Zachowany w Filokalii fragment komentarza do Pnp przedstawia faraona jako „byt materialny”, w świetle interpretacji, która wydaje się bardziej duchowa i i ostrożniejsza. Por. Philocalia XXVII,13; E. Junod, Origène. Philocalie, s. 310, przypis 2. 
nie chce ulec Jego cierpliwości. Ty, który spierasz się z Apostołem, wiedz, że próżne są słowa twoje: „Dlaczego Bóg czyni jeszcze wyrzuty? Któż bowiem woli Jego może się sprzeciwić?”. Oczywiście, woli Boga nikt się sprzeciwić nie może, jednak powinniśmy wiedzieć, że Jego wola jest sprawiedliwa i słuszna. Albowiem od naszej woli zależy, czy jesteśmy dobrzy, czy źli; od woli Boga natomiast zależy, na jaką karę przeznaczony zostaje zły, a do jakiej chwały dobry ${ }^{146}$.

Doktor aleksandryjski odrzuca interpretację dosłowną, przypisując określone działanie boskiej naturze, a cała kwestia w jego opinii dotyczy sprawiedliwości Bożej. W Filokalii „gorszącemu” twierdzeniu biblijnemu Orygenes przeciwstawia analogiczne sformułowania natchnionych tekstów ${ }^{147}$. W De principiis z kolei podkreśla, że chodzi o jego własną opinię ${ }^{148}$. Apeluje do błędniowierców o uczciwość intelektualną, przyjmując wyzwanie o przytoczenie dowodów interpretacji Wj zgodnej z ideą Boga sprawiedliwego i natchnionym charakterem Biblii. Uzasadnia więc swoje wysiłki, chociaż można było się przekonać, że nagana apostoła według Rz 9,20 ${ }^{149}$ wystarczała, by zamknąć dyskusję, która przybierała niebezpieczny obrót. Replika na temat Rz 9,19 odnosiła podobny skutek także wtedy, gdy św. Paweł odwoływał się do autorytetu swego apostolatu ${ }^{150}$. Na wzór apostoła narodów ${ }^{151}$, także Orygenes uwydatnia różnice w opowiadaniu pewnych epizodów biblijnych. Negowanie wolnej woli należy w ocenie Adamancjusz do insolentes quaestiones. Daje tego dowód łącząc z Rz 9 analogiczne problemy pojawiające się w narracji ewangelicznej ${ }^{152}$.

Orygenes uważał się po prostu za przewodnika, wprowadzającego w tajemnice Pisma Świętego. Wspomniana przez św. Pawła zatwardziałość faraona to wzbudzający „największą trwogę” epizod biblijny, tak więc nawet w innych komentarzach egzegeta aleksandryjski po prostu przedstawia słuchaczom tę tajemnicę ${ }^{153}$. Paradygmat „rozmówcy z Bogiem” nie stanowi bynajmniej apostoł narodów, lecz postać Mojżesza. To właśnie on posiada wszelkie przymioty

146 Commentarius in Rom. VII,16.

147 Por. Philocalia XXVII,1-2.

148 Por. De principiis III,1,10-11.

149 „Człowiecze! Kimże ty jesteś, byś mógł się spierać z Bogiem” (Rz 9,20). Por. De principiis III,1,22.

150 Por. Homiliae in Ex. IV,2.

151 Analogie biografii Orygenesa z postacią św. Pawła są raczej rzadkie. W ujęciu Euzebiusza z Cezarei w osobie Adamancjusza zbiegły się rysy Sokratesa i Chrystusa. Historyk Kościoła przypomina o prześladowaniach, jakie dotknęły wielkiego Aleksandryjczyka, podkreślając, iż jego życie było zgodne z najwyższą filozofią chrześcijaństwa i wiernym naśladowaniem Syna Bożego. Por. Historia ecclesiastica VI,15; 30.

152 Ta kwestia pojawia się w Commentarius in Rom. VII,17.

153 Por. Homiliae in Ex. IV,2. 
moralne i duchowe, by przekazać właściwą interpretację Bożych rozporządzeń. Pseudoalternatywą jest krytykowanie postanowień Stwórcy, przez tych, którzy nie mają do tego prawa. W gruncie rzeczy dociekania heretyków inspiruje chęć kontestacji, a nie umiłowania prawdy ${ }^{154}$. Wtedy właśnie błędnowierca zasługuje na twarde upomnienie apostoła, wskazującego na ludzkie ograniczenia.

Dodajmy, że podobnych kwestii jest bardzo wiele, stąd częste dygresje, wątki poboczne i różnorodność cytacji biblijnych, na których opiera się przebogaty wywód egzegety. Nie znaczy to jednak, ze ma się do czynienia z dziełem chaotycznym i nieuporządkowanym. Jednak uważna lektura dowodzi że biegłość Orygenesa egzegety i filologa oraz głębia jego teologicznych rozważań są zdolne sprowadzić refleksję nad tekstem Rz na właściwe tory i ukazać jedność kompozycyjną tekstu listu Pawłowego ${ }^{155}$.

\section{Zakończenie}

Potwierdzeniem szczególnego znaczenia, jakiego nabrała problematyka wolnej woli stanowi fakt, że Aleksandryjczyk powraca do tej tematyki niejednokrotnie i to w dziełach o różnym charakterze i przeznaczeniu. Nie sposób więc abstrahować od pism, które nie mają stricte charakteru egzegetycznego. Warto jednak pamiętać, że nad komentarzem orygenesowym ciąży brzemię tłumaczenia dokonanego przez Rufina z Akwilei, którzy w dużej mierze interpretował dzieło Aleksandryjczyka. Współcześni badacze są raczej zgodni odnośnie do obiektywnej wartości parafrazy Rufina, który raczej wolał pozostawać w cieniu i nie przypisywać sobie zbyt wielkich zasług. Ważne jest jednak konfrontowanie dostępnych źródeł.

Orygenes jest autorem ujmującym w sposób kompleksowy poszczególne zagadnienia. Mówi ogólnie o charakterystycznych przymiotach osoby ludzkiej, obdarzonej wolnością i możliwością samorealizacji. Doktor aleksandryjski oparł swoje rozważania na tradycyjnych wątkach polemiki z heretykami, podkreślając zawsze wolność człowieka i dynamizm dziejów stworzenia. Kwestię wolnej woli połączył więc łukiem wydarzeń historii rodzaju ludzkiego i innych bytów rozumnych: od upadku w prehistorii po odnowę wszystkiego w Chrystusie. Bez tego ważnego filara systemu filozoficznego, egzegetycznego i teologicznego nie sposób zrozumieć specyfiki kontrowersyjnych sformułowań Adamancjusza, lecz także optymizmu, jaki przenika jego myśl. Kwestie wolnej woli starał się rozpra-

154 Por. Homiliae in Ex. IV,2. i Commentarius in Rom. VII,17.

155 Znaczący jest sposób, w jaki Orygenes łączy część moralizującą listu (rozdz. 12-14) z jego wcześniejszymi sekcjami tematycznymi. Por. F. Cocchini, Origene. Commento alla lettera ai Romani, tom 2, s. XXVII-XXXII. 
cować Metody z Olimpu ${ }^{156}$, który jednak nie poświęcał się tworzeniu komentarzy egzegetycznych

Orygenes był pionierem egzegezy $\mathrm{Rz}$ i przez długi czas stanowił inspirację dla innych autorów. Podobnego dzieła podjął się prawdopodobnie dopiero Apolinary z Laodycei, który odczytywał tekst Pawłowy w stulecie po Orygenesie. Z pozostałych autorów greckich IV wieku listem do Rz zajmowali się Akacjusz z Cezarei, Dydym Aleksandryjski, Euzebiusz z Emezy i Diodor z Tarsu. Wcześniejszy komentarz przywołuje Hieronim ze Strydonu i wskazuje że jego autorem był Asteriusz Sofista ${ }^{157}$. Adamancjusz przetarł także szlak, aby tekst Rz 9 pojawił się nie tylko w kontekście egzegetycznym, ale także w ujęciu „katechizmowym”, jak chociażby na niektórych stronicach De principiis.

\section{Exegesis of Rom 9 and the Matter of Free Will in the Thought of Origen}

\section{Summary}

The question of free will is one of the most crucial theological topics for Origen. Inspired by the polemics of his time he was relentlessly and fervently defending the principle of free choice on the part of the rational being. Origen would refer to Rom 9 as to an important text supporting his view on the issue. The author of the article shows how Origen proves that the appropriate interpretation of the Pauline text sheds even more light and actually explains the Christian doctrine of free will.

156 Metody to jeden z oponentów Orygenesa. Por. L.G. Patterson, Methodius of Olympus: Divine Sovereignty, Human Freedom, and Life in Christ, Washington 1997.

157 Por. De viris illustribus 94. Nie zachował się żaden fragment tego komentarza. 